\title{
Article \\ Role of the Laparoscopic Approach for Complex Urologic Surgery in the Era of Robotics
}

\author{
Iulia Andras ${ }^{1,2,+} \oplus^{(}$, Angelo Territo ${ }^{3, \dagger}$, Teodora Telecan ${ }^{2, *}$, Paul Medan $^{2}\left(\mathbb{D}\right.$, Ion Perciuleac ${ }^{2}(\mathbb{D}$, \\ Alexandru Berindean ${ }^{2}$, Dan V. Stanca ${ }^{1,2}$, Maximilian Buzoianu ${ }^{1}$, Ioan Coman ${ }^{1,2}$ and Nicolae Crisan ${ }^{1,2}$ \\ 1 Department of Urology, Iuliu Hatieganu University of Medicine and Pharmacy, \\ 400012 Cluj-Napoca, Romania; dr.iuliaandras@gmail.com (I.A.); vasilestanca@yahoo.com (D.V.S.); \\ maximilian.buzoianu@yahoo.com (M.B.); jcoman@yahoo.com (I.C.); drnicolaecrisan@gmail.com (N.C.) \\ 2 Department of Urology, Municipal Hospital, 400139 Cluj-Napoca, Romania; medan.paul@gmail.com (P.M.); \\ ion.perciuleac@yahoo.com (I.P.); dr.berindean@gmail.com (A.B.) \\ 3 Uro-Oncology and Kidney Transplantation Unit, Department of Urology, Fundacio Puigvert, \\ Autonoma University of Barcelona, 08025 Barcelona, Spain; territoangelo86@gmail.com \\ * Correspondence: t.telecan@gmail.com \\ + These authors contributed equally.
}

Citation: Andras, I.; Territo, A.;

Telecan, T.; Medan, P.; Perciuleac, I.; Berindean, A.; Stanca, D.V.; Buzoianu, M.; Coman, I.; Crisan, N. Role of the Laparoscopic Approach for Complex Urologic Surgery in the Era of Robotics. J. Clin. Med. 2021, 10, 1812. https://doi.org/10.3390/jcm10091812

Academic Editor: Yair Lotan

Received: 17 March 2021

Accepted: 20 April 2021

Published: 21 April 2021

Publisher's Note: MDPI stays neutral with regard to jurisdictional claims in published maps and institutional affiliations.

Copyright: (c) 2021 by the authors. Licensee MDPI, Basel, Switzerland. This article is an open access article distributed under the terms and conditions of the Creative Commons Attribution (CC BY) license (https:// creativecommons.org/licenses/by/ $4.0 /)$.

\begin{abstract}
Introduction: The advent of robotic surgery led to the assumption that laparoscopic surgery would be replaced entirely. However, the high costs of robotic surgery limit its availability. The aim of the current study was to assess the feasibility of the 3D laparoscopic approach for the most complex urological procedures. (2) Materials and methods: We included in the current study all patients who had undergone complex 3D laparoscopic procedures in our department since January 2017, including radical nephrectomy (LRN) using a dual combined approach (19 patients), radical nephroureterectomy (LRNU) with bladder cuff excision (13 patients), and radical cystectomy (LRC) with intracorporeal urinary diversion (ICUD) (21 patients). (3) Results: The mean operative time was $345 / 230 / 478 \mathrm{~min}$, the complications rate was $26 \% / 30.76 \% / 23.8 \%$ and positive surgical margins were encountered in 3/1/1 patients for the combined approach of LRN/LRNU/LRC with ICUD, respectively. A single patient was converted to open surgery during LRN due to extension of the vena cava thrombus above the hepatic veins. After LRC, sepsis was the most common complication and 8 patients were readmitted at a mean of 15.5 days after discharge. (4) Conclusions: In the era of robotic surgery, laparoscopy remains a plausible alternative for most complex oncological cases.
\end{abstract}

Keywords: 3D laparoscopy; dual combined approach; radical cystectomy; radical nephroureterectomy; robotic surgery

\section{Introduction}

Minimally invasive surgery has delivered great benefits for patients, improving perioperative outcomes such as estimated blood loss, postoperative pain, and wound infection and reducing the average hospital stay as compared with that following open surgery [1]. Studies assessing the quality of life $(\mathrm{QoL})$ after surgery have shown that, in comparison to open procedures, minimally invasive procedures achieve better mental QoL 2 days after the intervention and better physical QoL at 1 month [2]. Furthermore, similar oncologic and functional postoperative outcomes have been reported for several surgical procedures when comparing open and minimally invasive approaches [3].

While minimally invasive surgery was initially reserved for selected cases, the introduction of robotic surgical systems has allowed its use in more complex and challenging procedures [4]. By the end of 2017, 5770 platforms had been shipped worldwide, the total revenue being estimated at US $\$ 3.1$ billion dollars, and more than 877,000 robotic procedures were performed globally in that year, mainly in the fields of general surgery, gynecology, and urology [5]. Another study found that robotic surgery was used 8.4 times more frequently in 2018 compared with 2012 [6]. 
At first it was thought that laparoscopic surgery would ultimately be replaced entirely by the robotic approach, but the development of improved laparoscopic systems opened up new possibilities [7]. Three-dimensional (3D) laparoscopy has gained increasing popularity, providing quality in-depth vision of the work space and reducing the overall task performance time, the frequency of technical errors, and the cognitive strain and workload faced by surgeons when using 2D systems. In addition, the price of a fully equipped 3D laparoscopic tower can be as little as a tenth of the usual cost of a surgical robot [8].

Traditionally, the major drawbacks of a laparoscopy have been considered to be rigid instruments with only 4 degrees of movement, which accentuates the fulcrum effect, and a steep learning curve [9]. Recent studies have proven that novice surgeons perform tasks with a superior outcome and time record when using 3D vision as compared with conventional laparoscopy [10]. In addition, 3D vision shortens the learning curve and adds precision when performing tasks previously considered difficult, such as suturing and needle guidance and transfer, making laparoscopy a viable option for routine procedures. The problems that arise are in the complex surgeries that involve extensive suturing and reconstruction [11]. Procedures such as a radical nephrectomy with thrombectomy, a nephroureterectomy with bladder cuff excision, and a radical cystectomy with intracorporeal urinary diversion are often considered off limits for the laparoscopic approach.

The aim of the current study was to assess the feasibility of a 3D laparoscopic approach for the most complex urological procedures, as a viable alternative to robotic surgery.

\section{Materials and Methods}

\subsection{Patient Selection}

We included in the current study all patients who had undergone complex 3D laparoscopic procedures in our department since January 2017, including a radical nephrectomy (LRN) using the dual combined approach, a radical nephroureterectomy with bladder cuff excision (LRNU), and a radical cystectomy (LRC) with intracorporeal urinary diversion (ICUD). The study was conducted in accordance with the Declaration of Helsinki and all patients signed the informed consent form. All procedures were performed by a single surgeon (NC), who had 6 years of experience in open and robot-assisted urooncological surgery prior to the introduction of 3D laparoscopy in our department in 2017. Since then, all surgeries, except very few selected cases, have been performed by the laparoscopic approach.

\subsection{Surgical Technique}

\subsubsection{Dual Combined Approach for Renal Tumors with Invasion of the Renal Vein or} Inferior Vena Cava (IVC)

The dual combined laparoscopic approach comprised retroperitoneal access for artery and lumbar vein ligation, followed by transperitoneal access for completion of surgery and thrombectomy. For the retroperitoneal approach, three working trocars were positioned in a triangular manner as previously described [12,13] (Figure 1). An additional $5 \mathrm{~mm}$ additional trocar was placed for the assistant surgeon.

After opening Gerota's fascia, the renal artery was isolated, clipped, and sectioned. All the identified lumbar veins were sealed and divided and the posterior wall of the inferior vena cava (IVC) was extensively dissected. For the transperitoneal approach, three out of four trocars were repositioned (Figure 1). In some cases, a second $5 \mathrm{~mm}$ trocar was positioned in the epigastric area to facilitate liver retraction. The ipsilateral colon was dissected medially. The renal vein was isolated carefully in order to prevent tumor embolization. Dissection continued until the level of junction between the suprahepatic veins and IVC. On the right side, the central adrenal vein was clipped and divided.

For level 0 thrombus patients, the tumor was milked entirely inside the renal vein, the latter being clipped as close to the IVC as possible, avoiding the cavotomy. For more advanced cases, the venous system was occluded using vessel loops and Rummel tourniquets in the following order: IVC below the renal pedicle, contralateral renal vein, 
and IVC above the thrombus. Cavotomy was performed, removing the entire tumoral thrombus. After heparinization, double-layered cavorrhaphy was performed, and the tourniquets undone in reverse order. The kidney was removed in an endobag through an inguinal incision.
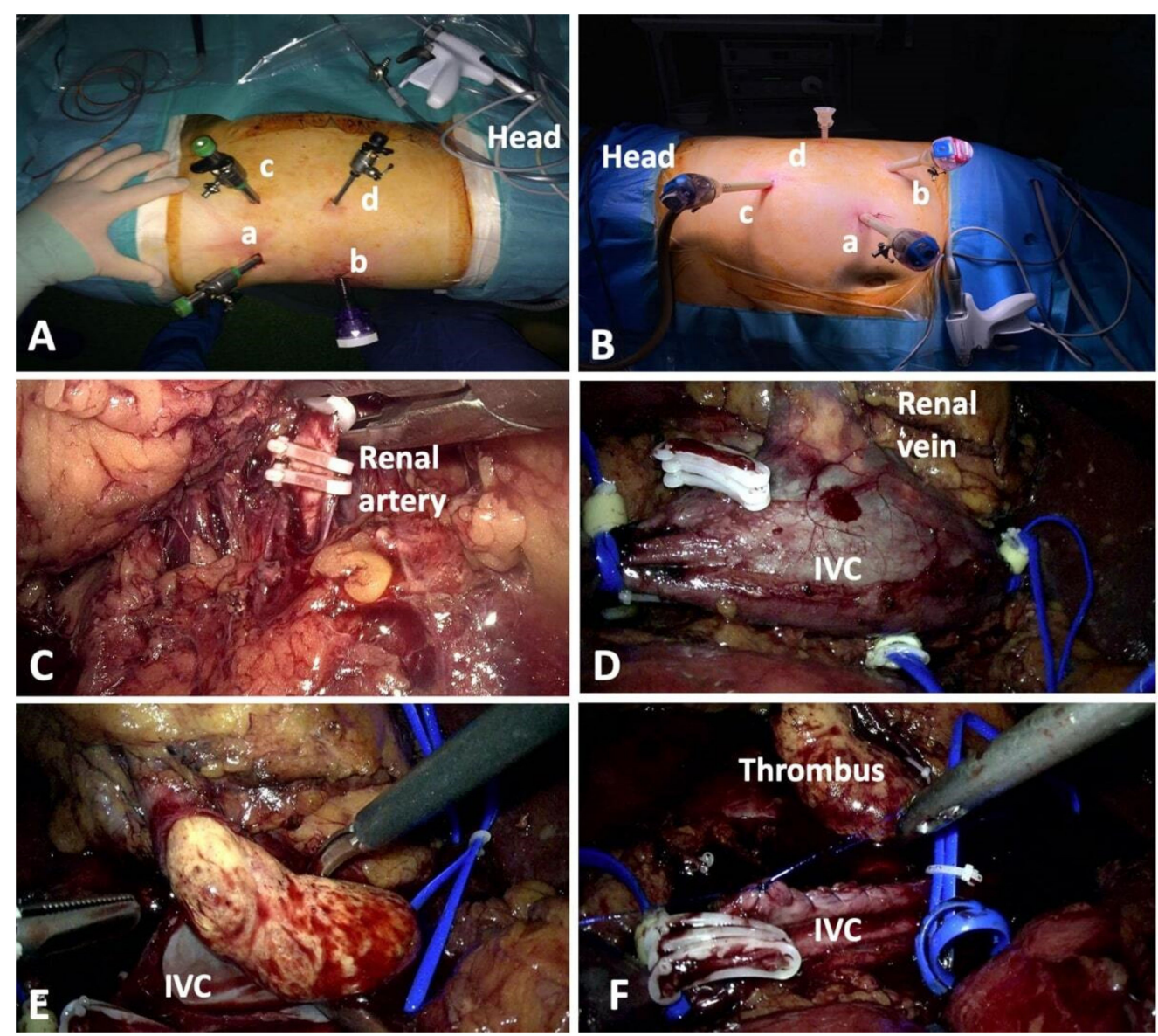

Figure 1. (A) Trocar positioning for the retroperitoneal approach in upper urinary tract surgery-left side. The $10 \mathrm{~mm}$ optic trocar (a) was placed on the mid-axillary line, above the iliac crest. Two 10 to $12 \mathrm{~mm}$ trocars were used, one located in the costomuscular angle (b), below the costal margin, and the second situated on the anterior axillary line, $2 \mathrm{~cm}$ above the anterior iliac spine (c). An additional $5 \mathrm{~mm}$ trocar was placed midway between the costal margin and the last trocar (d). (B) The optic trocar (a) was moved paraumbilically, at the lateral margin of the rectus abdominis muscle. One of the working trocars was placed on the line between the umbilicus and the anterior iliac spine (b), $2 \mathrm{~cm}$ cranially from the latter, and the second working trocar was inserted on the line linking the costal margin with the umbilicus at a right angle, $2 \mathrm{~cm}$ below the ribs (c). The additional 5-mm trocar used by the assisting surgeon was left in its initial location (d). (C) Clipping of the renal artery by retroperitoneal approach. (D) Inferior vena cava (IVC) isolation and occlusion. (E) Complete extraction of the tumor thrombus from the IVC by transperitoneal approach. (F) Final aspect of cavorraphy.

\subsubsection{Nephroureterectomy with Bladder Cuff Excision}

The approach was transperitoneal and the trocars were placed in a standard manner (Figure 2). The trocar for the assisting surgeon was placed either in the epigastrium (right side) or midway between the costal rim and the anterosuperior iliac spine (left side).

The ureter was clipped below the tumor to decrease the risk of caudal tumor seeding and a radical nephrectomy was performed, without kidney dissection from the lateral abdominal wall.

In order to manage the distal ureter and to perform the excision of the bladder cuff, the surgical table was tilted to a Trendelenburg position and rotated to ensure $60^{\circ}$ lateral 
decubitus. In some cases, an additional $5 \mathrm{~mm}$ trocar was inserted in the suprapubic area. For the pelvic dissection, the surgeon used the new additional trocar and the one situated above the iliac spine, whereas the paraumbilical trocar and the one located below the ribs were used for the camera. If no supplementary trocar was employed, the camera was repositioned through the trocar below the ribs and the main surgeon used as working trocars the one above the iliac spine or the former camera trocar. The isolation of the ureter was further extended, until its opening into the bladder wall was reached. Bladder cuff excision was performed after careful inspection of the inner wall of the bladder to identify the contralateral ureteral orifice. Before finalizing the partial cystectomy, the first suture was placed in order to prevent bladder retraction and ease further identification. The cystorrhaphy was carried out in a double-layered manner using a barbed suture, then verified by instilling $200-300 \mathrm{~mL}$ of saline.
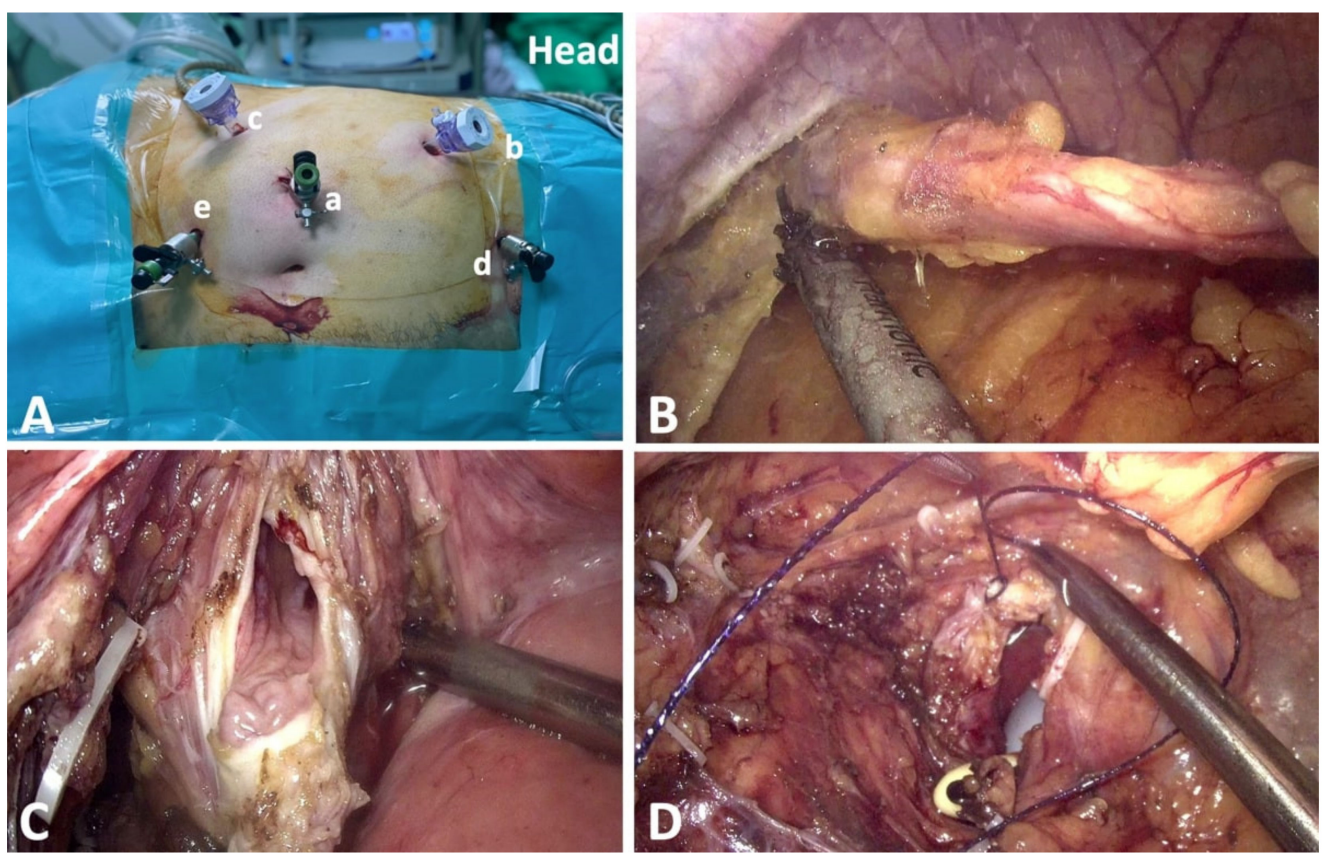

Figure 2. (A) Trocar positioning for right side laparoscopic transperitoneal radical nephroureterectomy with bladder cuff excision (a-d); suprapubic supplementary trocar used for pelvic dissection (e). (B) Isolation of the ureter in the pelvic segment. (C) Resection of the bladder cuff by the laparoscopic approach. (D) Cystorraphy using barbed suture.

\subsubsection{Radical Cystectomy with Intracorporeal Urinary Diversion}

The patient was placed in dorsal decubitus, with the operating table tilted in the Trendelenburg position. Five trocars were used (Figure 3).

A frozen section of the ureteral stumps was performed in all patients. The prostatectomy was carried out in a nerve-sparing fashion, when safe from an oncological standpoint. Lymphadenectomy was performed in all patients and comprised the removal of the obturator, internal, external and common iliac nodes. In female patients, the anterior vaginal wall was resected en bloc with the cystectomy specimen.

For the urinary diversion, the left ureter was transposed on the right side through the mesosigmoid. Intracorporeal neobladder (NB) was constructed using modified Studer technique. The anastomosis with the urethral stump was done in the van Velthoven manner using barbed suture. To prevent tension in the anastomosis, the Rocco stitch was performed in some cases. Gastrointestinal continuity was reestablished using laparoscopic staplers. The ureters were anastomosed in Wallace 1 or 2 manner then catheterized using percutaneously inserted mono-J stents. The ureteral stents were inserted in the neobladder either through the anterior wall or through the suture. The watertightness of the reservoir was checked using $50 \mathrm{~mL}$ of sterile saline. 

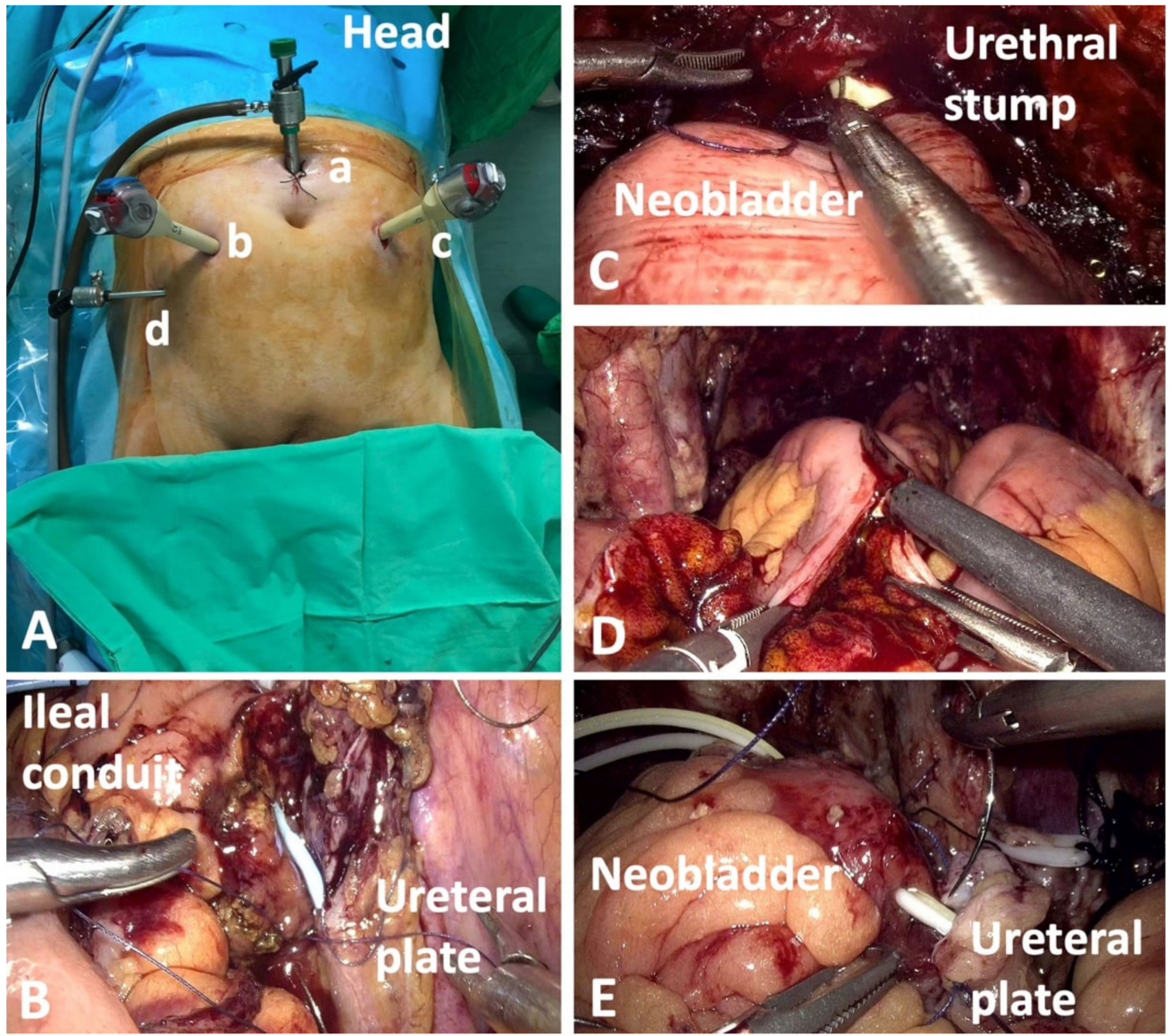

Figure 3. (A) Trocar positioning for laparoscopic radical cystectomy: the 10-mm optic trocar (a) was placed $2 \mathrm{~cm}$ superior to the umbilicus and two 12-mm instrument trocars were situated at the umbilical level, approximately $8 \mathrm{~cm}$ from the camera trocar, one on each side (b,c). An additional 5-mm trocar (d), for the assistant surgeon, was positioned above the iliac crest. (B) The anastomosis between the ureteral plate and the ileal conduit. (C) Anastomosis between the urethra and the neobladder performed by the laparoscopic approach. (D) Detubularization of the excluded intestinal loop. (E) The anastomosis between the ureteral plate and the neobladder.

For ileal conduit (IC) a $20 \mathrm{~cm}$ bowel segment was used. The ureters were sutured to the proximal end of the IC in Wallace 1 or 2 type anastomosis. Mono-J or double-J stents were used for ureteral catheterization.

\subsection{Follow-Up}

Follow-up after LRN with venous thrombus comprised chest and abdomen computed tomography (CT) scan at 3 and 6 months after surgery, followed by repeat imaging at every 6 months thereafter. Patients who underwent LRNU were followed-up by cystoscopy at every 3 months during the first two years and at 6 months thereafter. A chest and abdomen CT scan was performed every 6 months. In patients who underwent LRC, follow-up included a visit at 3-4 weeks after surgery for ureteral stent and/or Foley catheter removal. Imaging comprising chest and abdomen CT scan was performed at 3 and 6 months after surgery and at 6 months thereafter.

\section{Results}

A total of 19 patients (14 males, 5 women) underwent a combined approach LRN for renal cell carcinoma with venous thrombus. Their mean age was 67 years (range 53-80). In $73.7 \%$ of cases the tumor was located in the right kidney, and in $26.3 \%$ in the left. The mean tumor size was $7.9 \mathrm{~cm}$ (range 4.5-13). Two patients had a history of prior abdominal 
surgeries. A cavotomy was performed in 8 patients, all of whom had a right kidney tumor. In the other 11 patients, thrombus retraction after arterial clamping and retrograde milking allowed ligation of the renal vein, without the need for cavotomy. Perioperative data are summarized in Table 1. Postoperative staging was pT3a in 11 patients and pT3b in 8 patients. The rate of positive surgical margins (PSM) was 15.78\% (3 cases), all due to thrombus microscopic invasion of the wall of the renal vein. The postoperative complication rate was $26 \%$ (5.26\% Clavien $\geq \mathrm{III})$. Nine patients received adjuvant Sunitinib (3 with PSM and 6 with oligometastatic disease). Median follow-up was 18 months (range 3-26). At the last follow-up, 18/19 patients were alive. One patient died at 2 years after surgery with local and metastatic recurrence of the disease.

LRNU with complete laparoscopic bladder cuff excision was performed for high-risk upper tract urothelial carcinoma in 13 patients (6 males, 7 females) with a mean age of 64 years (range 55-85). Perioperative data are summarized in Table 1 . The mean number of lymph nodes was 3.5 (range 2-8). Pathology confirmed the presence of urothelial carcinoma, staged as pT1 in 5 patients, pT2 in 4 patients, and pT3 in 3 patients. In one patient, the ureteral tumor was identified as breast carcinoma metastasis. The rate of PSM was $7.69 \%$ (at the bladder wall for the patient with metastatic breast carcinoma). The mean catheterization time was 14 days (range 7-24). The postoperative complication rate was $30.76 \%$ (7.69\% Clavien $\geq$ III). The median follow-up was 9 months (range 3-18). At the last follow-up, 11/13 patients were alive. During follow-up, one patient was diagnosed with chylous ascites for which repeated paracentesis was performed.

Twenty-one patients (19 males, 2 females) underwent LRC with ICUD. The mean age of the patients was 64 years (range 48-75). Intracorporeal NB was performed in 7 cases and IC in 14. Uretero-ileal anastomosis was performed in the Wallace 1 manner in 10 cases (4 IC, 6 NB) and the Wallace 2 manner in 11 cases (10 IC, 1 NB). Mono-J stents were used for ureteral drainage in all cases, except for three patients with IC, and were removed at 20 days (range 14-31) after surgery for NB and at 35 days (range 14-55) after surgery for IC. In patients with NB, the Foley catheter was removed at 28 days (range 21-30), following a control cystogram. The rate of 30 -days postoperative complications was $23.8 \%$ ( $4.76 \%$ Clavien $\geq$ III). Eight patients were readmitted at a mean of 15.5 days for sepsis. Pathologic staging confirmed the presence of urothelial carcinoma in 19 cases and squamous cells carcinoma in 2 cases. The bladder tumor was staged as pT0 in 3 patients, pTis in 2 patients, pT1 in 5 patients, pT2 in 3 patients, and pT3 in 8 patients. The mean number of retrieved lymph nodes was 13 (range 6-33). Positive lymph nodes were encountered in 3 patients. One patient had a PSM (right lateral wall of the bladder, pT3b). The mean follow-up was 12 months (range 2-20). At the last follow-up, one patient had died due to stroke. All but one of the patients with NB were continent during the day at 6 months (using 0-1 pads). 
Table 1. Three-dimensional complex laparoscopic procedures performed in our department.

\begin{tabular}{|c|c|c|c|c|c|c|c|c|}
\hline $\begin{array}{l}\text { No. of } \\
\text { Patients }\end{array}$ & $\begin{array}{l}\text { Preoperative } \\
\text { Information }\end{array}$ & Procedure Specifics & $\begin{array}{c}\text { Operative Time *, } \\
\text { Minutes } \\
\text { Mean (Range) }\end{array}$ & $\begin{array}{l}\text { Blood Loss, mL } \\
\text { Mean (Range) }\end{array}$ & Conversion, Reason & $\begin{array}{c}\text { Length of } \\
\text { Hospital Stay, } \\
\text { Days } \\
\text { Median (Range) }\end{array}$ & $\begin{array}{l}30 \text { days Postoperative } \\
\text { Complications }\end{array}$ & Oncologic Outcomes \\
\hline \multicolumn{9}{|c|}{ Radical nephrectomy with thrombectomy by dual combined laparoscopic approach } \\
\hline 19 & $\begin{array}{l}\text { Mayo classification } \\
\text { Level 0-8 patients } \\
\text { Level I-7 patients } \\
\text { Level II-4 patients }\end{array}$ & $\begin{array}{l}\text { Cavotomy- } 8 \text { patients } \\
\text { No cavotomy-11 } \\
\text { patients }\end{array}$ & $\begin{array}{l}\text { Cavotomy: } 361 \mathrm{~min} \\
(280-555) \text { No } \\
\text { cavotomy: } \\
330 \text { min }(175-400)\end{array}$ & $\begin{array}{c}350 \mathrm{~mL} \\
(150-600)\end{array}$ & $\begin{array}{c}1 \text { case, extension of } \\
\text { the thrombus above } \\
\text { the suprahepatic } \\
\text { veins }\end{array}$ & $\begin{array}{c}6 \\
(4-14)\end{array}$ & $\begin{array}{c}\text { Overall rate } 26 \% \\
\text { Clavien I-3 patients (port } \\
\text { site hematoma/prolonged } \\
\text { lymphatic drainage) } \\
\text { Clavien II-1 patient } \\
\text { (transfusion) } \\
\text { Clavien IV-1 patient } \\
\text { (pulmonary } \\
\text { thrombembolism) }\end{array}$ & $\begin{array}{l}\text { PSM 15.78\% } \\
\text { New onset metastatic } \\
\text { disease-2 patients } \\
\text { Local and metastatic } \\
\text { recurrence-1 patient } \\
\text { (converted case) }\end{array}$ \\
\hline \multicolumn{9}{|c|}{ Laparoscopic nephroureterectomy with bladder cuff excision } \\
\hline 13 & $\begin{array}{c}4 \text { patients with } \\
\text { synchronous bladder } \\
\text { tumor } \\
\text { 3-TaG1 } \\
\text { 1-T1G3 } \\
\text { (TURBT before surgery) }\end{array}$ & $\begin{array}{l}\text { Transperitoneal } \\
\text { approach }\end{array}$ & $230.38 \min (150-365)$ & $\begin{array}{c}100 \mathrm{~mL} \\
(50-200 \mathrm{~mL})\end{array}$ & None & $\begin{array}{c}7 \\
(4-8)\end{array}$ & $\begin{array}{c}\text { Overall rate } 30.76 \% \\
\text { Clavien I-1 patient (surgical } \\
\text { site infection) } \\
\text { Clavien II-2 patients } \\
\text { (transfusion) } \\
\text { Clavien V-1 patient (death } \\
\text { due to hemorrhagic } \\
\text { diathesis) }\end{array}$ & $\begin{array}{c}\text { PSM 7.69\% } \\
\text { Adjuvant } \\
\text { chemotherapy-6 } \\
\text { patients } \\
\text { Bladder recurrence at } 6 \\
\text { months-1 patient } \\
\text { Metastatic progression of } \\
\text { disease and death at } \\
12 \text { months (breast } \\
\text { carcinoma) - } 1 \text { patient }\end{array}$ \\
\hline \multicolumn{9}{|c|}{ Laparoscopic radical cystectomy with intracorporeal urinary diversion } \\
\hline 21 & $\begin{array}{c}\text { MIBC-16 patients } \\
\text { High-risk NMIBC-5 cases } \\
\text { Neoadjuvant } \\
\text { chemotherapy-10 cases } \\
\text { No neoadjuvant } \\
\text { chemotherapy in } 6 \text { cases } \\
\text { of MIBC due to-histology } \\
\text { (squamous cell } \\
\text { carcinoma-2 cases), renal } \\
\text { function impairment (4 } \\
\text { cases) }\end{array}$ & $\begin{array}{l}\text { NB-7 cases } \\
\text { IC-14 cases }\end{array}$ & $\begin{array}{c}\text { NB: } 496.27 \mathrm{~min} \\
\text { (490-710) IC: } \\
461.09 \text { min (350-550) }\end{array}$ & $\begin{array}{c}200 \mathrm{~mL} \\
(100-400 \mathrm{~mL})\end{array}$ & None & $\begin{array}{c}13 \\
(6-29)\end{array}$ & $\begin{array}{c}\text { Overall rate } 23.8 \% \\
\text { Clavien I-2 patients } \\
\text { (delirium, urinary fistula in a } \\
\text { patient with IC which was } \\
\text { managed conservatively) } \\
\text { Clavien II-2 patients (sepsis } \\
\text { requiring antibiotic, digestive } \\
\text { bleeding requiring } \\
\text { transfusions) } \\
\text { Clavien IIIb-one patient } \\
\text { (reoperation for bleeding) }\end{array}$ & $\begin{array}{c}\text { PSM } 4.76 \% \\
\text { Local recurrence-1 } \\
\text { patient } \\
\text { New onset metastatic } \\
\text { disease-1 patient }\end{array}$ \\
\hline
\end{tabular}

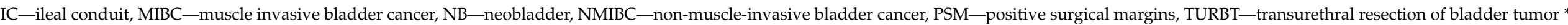

Operative time included total operating room time (anesthesia and procedure). 


\section{Discussion}

In the era of robotic surgery, interest in laparoscopy has decreased due to the steep learning curve and the work ergonomy for the surgeon. Despite its unquestionable advantages, however, robotic surgery takes an important toll on healthcare systems due to its significant cost. It is important not to deprive patients of the advantages of a minimally invasive approach. The data presented here support the feasibility of the 3D laparoscopic approach for the most complex uro-oncological procedures.

Radical nephrectomy with thrombectomy is considered by most practitioners as "the touchstone of urology". The dual approach presented in this report delivers the benefits of each technique: the retroperitoneal access allows fast ligation of the renal artery, facilitating tumor ischemia and thrombus retraction and thus reducing the risk of embolization. On the other hand, the transperitoneal route ensures quick access to the venous system with minimal manipulation, while providing a generous working space to isolate the IVC and perform the thrombectomy.

The dual combined laparoscopic approach has been shown to be feasible by other authors as well. Sanli et al. [14] reported the first two cases of use of the combined laparoscopic approach for radical nephrectomy and IVC thrombectomy in 2013. Using 3 trocars for each approach, they performed the intervention on tumors with level I thrombus extension. The total insufflation time was 150 and $165 \mathrm{~min}$. In the first case, cavotomy and cavorrhaphy were performed, while in the second, milking the thrombus back into the renal vein and applying $2 \mathrm{Hem}-\mathrm{o}-\mathrm{Lok}^{\mathrm{TM}}$ clips sufficed. The patients were discharged at postoperative days 5 and 4 . One of the patients developed lung metastasis 15 months after the surgery. Tang et al. [15] reported the case of a patient with a 6.4-cm right-sided tumor with level II thrombus who underwent a similar approach. No significant postoperative complications were reported by the authors. In contrast to previous reports, we employed 4 trocars for the retroperitoneal approach and 4 to 5 trocars for the transperitoneal approach. We believe that the additional 5-mm retroperitoneal trocar facilitated the exposure of the renal pedicle and IVC, while the transperitoneal ones provided multiple working channels for auxiliary instruments, reducing manipulation of the IVC and renal vein.

Laparoscopic and robotic approaches have shown similar perioperative outcomes in patients with level I and II thrombus in terms of operative time, rate of major complications and oncologic outcomes (Table 2). However, there are still limits to use of the laparoscopic approach for IVC thrombectomy. Tumors with thrombus extending higher than the suprahepatic veins preclude the laparoscopic approach due to the impossibility of IVC isolation above the thrombus. In these cases, robotic surgery could represent a possibility. Chopra et al. [16] reported their experience in 11 patients with level III IVC thrombus, showing that the robotic approach enables isolation of the short hepatic veins and exposure of the retrohepatic IVC cranial to the thrombus. Furthermore, Gill et al. [17] reported their experience with level IV thrombectomy using the robotic approach. After securing the porta hepatis, infrarenal and retrohepatic IVC, and contralateral renal vein, a minithoracotomy was carried out in order to clamp the aorta and cardiopulmonary bypass was employed for complete thrombus extraction. Nonetheless, these procedures carry a significant risk of perioperative morbidity and thus should be reserved for highly experienced centers. 
Table 2. Literature overview of laparoscopic and robotic radical nephrectomy with IVC thrombectomy.

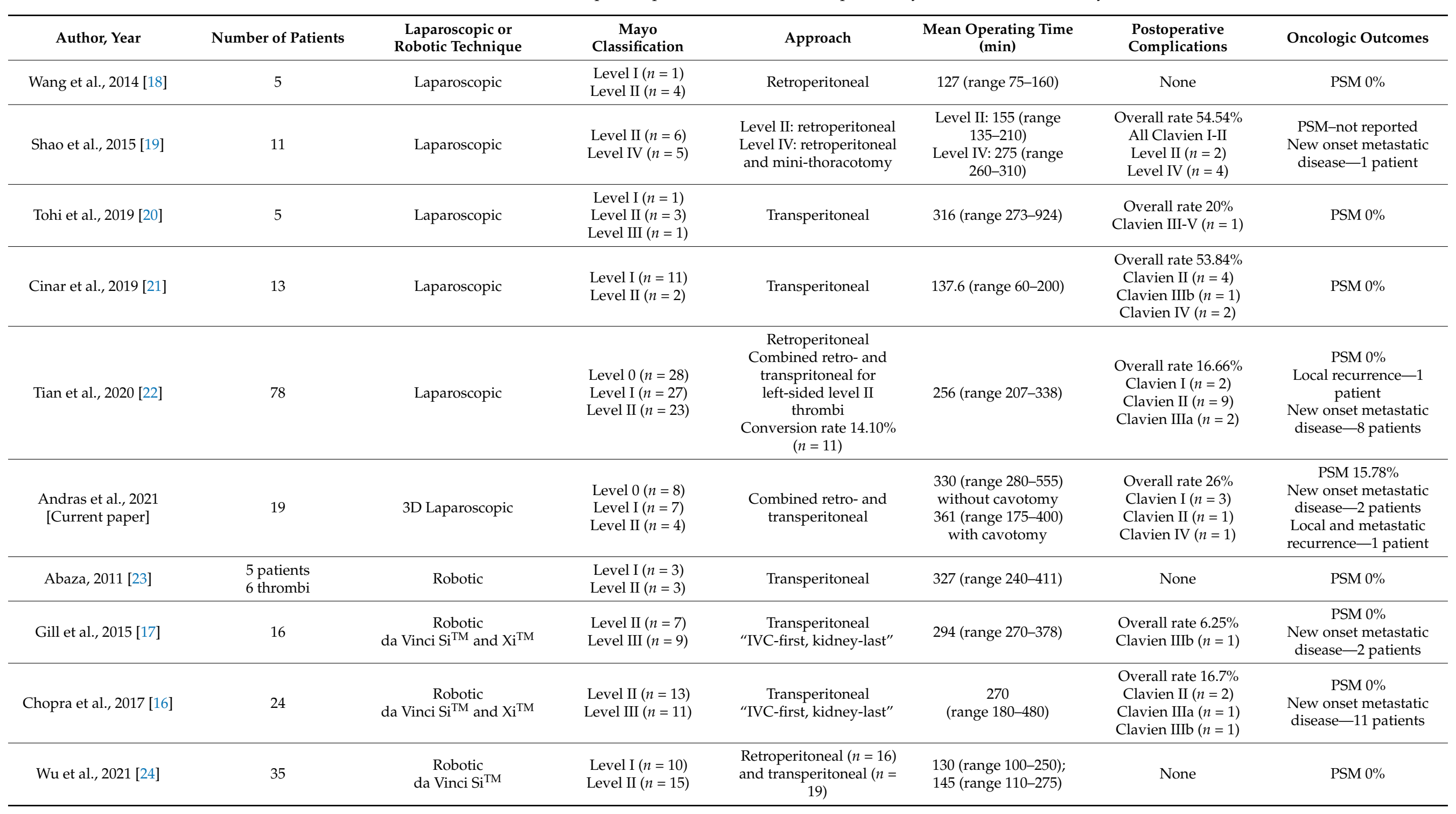


When performing radical nephroureterectomy, it is crucial to remove the ureteral stump since the recurrence rate at this site, if not properly excised, ranges between 30\% and 75\% [25]. Even when the radical nephroureterectomy is performed by the minimally invasive approach, open access by Gibson incision is most frequently used for bladder cuff excision. However, the implantation of the ureter into the urinary bladder is deep in the pelvis and the open approach does not always confer the best vision. Consequently, the quality of the partial cystectomy remains questionable in some cases. Laparoscopy can ensure better access and visualization in the pelvis, allowing a completely endoscopic approach, as shown by our experience, with correct identification of all anatomic elements. Several reports have been published confirming the feasibility of a laparoscopic approach for nephroureterectomy with bladder cuff excision. Ghazi et al. [26] published a case series of 8 patients, using a supplementary trocar for pelvic access as well. In this series, the surgeon performed first the excision of the terminal ureter and bladder cuff, and then the radical nephrectomy. Indeed, having the kidney attached to the abdominal wall ensures tension on the ureter and facilitates its dissection. We prefer to perform the nephrectomy first, and leave the kidney attached only to the abdominal wall. After bladder cuff excision we immediately place the ureteral stump into the endobag, aiming to limit the contact between the mucosa and surrounding tissues in order to decrease the risk of peritoneal tumor seeding.

Another possibility for performance of bladder cuff excision by the laparoscopic approach was described by Liu et al. [27] in a series of 31 patients. The authors reported use of a bulldog vascular clamp, which was modified to suit the curvature of the bladder, in order to clamp the perimeatic area. In this technique the forceps is inserted through a dedicated suprapubic trocar and approximates the walls, preventing urine spillage until the bladder cuff excision is performed.

A completely retroperitoneal approach is also feasible for this procedure, as shown by $\mathrm{Wu}$ et al. in a study of 48 patients [28]. Four trocars were used for this technique, 3 in standard fashion plus an additional $5 \mathrm{~mm}$ trocar placed on the midclavicular line, $3 \mathrm{~cm}$ below the umbilical level. The dissection of the ureter in the pelvic segment and bladder cuff were managed using the additional port and the one placed above the iliac crest and was feasible in all cases. Moreover, Hattori et al. [29] suggest placing a stay suture at the anterior wall of the bladder and suspending it transabdominally. By applying tension to both the bladder and the ureter (which is grasped and tractioned cranially), the junction between the two structures is better exposed and circumferential dissection is facilitated in the retroperitoneal approach.

As shown hereby, different techniques have been employed for nephroureterectomy with bladder cuff excision and have demonstrated the feasibility of a complete laparoscopic approach. When comparing series reporting laparoscopic and robotic radical nephroureterectomy with bladder cuff excision, no significant differences were observed for the operative time and major complications rate or oncologic outcomes (Table 3). On the other hand, the open approach for radical nephroureterectomy has shown lower 5-year cancer-specific survival as compared with minimally invasive techniques [30]. 
Table 3. Literature overview of laparoscopic and robotic nephroureterectomy with bladder cuff excision.

\begin{tabular}{|c|c|c|c|c|c|c|}
\hline Author, Year & $\begin{array}{l}\text { Number of } \\
\text { Patients }\end{array}$ & $\begin{array}{l}\text { Laparoscopic or } \\
\text { Robotic Technique }\end{array}$ & Approach & $\begin{array}{c}\text { Mean Operating Time } \\
\text { (min) }\end{array}$ & $\begin{array}{l}\text { Postoperative } \\
\text { Complications }\end{array}$ & Oncologic Outcomes \\
\hline Ghazi et al., 2010 [26] & 8 & $\begin{array}{l}\text { Laparoscopic } \\
\text { Remote controlled } \\
\text { robotic arm used for } \\
\text { optic guidance }\end{array}$ & $\begin{array}{l}\text { Transperitoneal } \\
\text { "Ureter first, nephrectomy last" } \\
\text { Extravesical bladder cuff }\end{array}$ & $\begin{array}{c}157 \\
\text { (range 110-200) }\end{array}$ & $\begin{array}{c}\text { Overall rate } 12.5 \% \\
\text { Bladder extravasation }(n=1)\end{array}$ & $\begin{array}{c}\text { PSM } 8.33 \% \\
\text { Bladder recurrence-3 } \\
\text { patients } \\
\text { Local and metastatic } \\
\text { recurrence-1 patient }\end{array}$ \\
\hline Gillan et al., 2013 [31] & 6 & Laparoscopic & $\begin{array}{c}\text { Transperitoneal } \\
\text { Extravesical bladder cuff }\end{array}$ & $190(180-240)$ & None & PSM $0 \%$ \\
\hline Liu et al., 2016 [27] & 31 & Laparoscopic & $\begin{array}{c}\text { Transperitoneal } \\
\text { Modified bladder cuff bulldog } \\
\text { clamp }\end{array}$ & $\begin{array}{c}146.6 \\
\text { (range 90-257) }\end{array}$ & None & $\begin{array}{c}\text { PSM } 0 \% \\
\text { No recurrence }\end{array}$ \\
\hline Wu et al., 2020 [28] & 48 & Laparoscopic & $\begin{array}{l}\text { Retroperitoneal } \\
\text { Extravesical bladder cuff }\end{array}$ & $\begin{array}{c}110 \\
\text { (range 100-130) }\end{array}$ & None & $\begin{array}{c}\text { PSM } 0 \% \\
\text { No recurrence }\end{array}$ \\
\hline Miyake et al., 2020 [32] & 4 & Laparoscopic & $\begin{array}{c}\text { Retroperitoneal } \\
\text { Transvesical bladder cuff }\end{array}$ & $\begin{array}{c}174 \\
\text { (range 171-202) }\end{array}$ & $\begin{array}{l}\text { Overall rate } 50 \% \\
\text { Clavien I }(n=1) \\
\text { Clavien II }(n=1)\end{array}$ & $\begin{array}{c}\text { PSM } 0 \% \\
\text { No recurrence }\end{array}$ \\
\hline $\begin{array}{l}\text { Andras et al., } 2021 \\
\text { [Current paper] }\end{array}$ & 13 & 3D Laparoscopic & $\begin{array}{l}\text { Transperitoneal } \\
\text { Extravesical bladder cuff }\end{array}$ & 230.38 (range $150-365$ ) & $\begin{array}{l}\text { Overall rate } 30.76 \% \\
\text { Clavien I }(n=1) \\
\text { Clavien II }(n=2) \\
\text { Clavien V }(n=1)\end{array}$ & $\begin{array}{c}\text { PSM } 7,69 \% \\
\text { Bladder recurrence-1 } \\
\text { patient }\end{array}$ \\
\hline Campi et al., 2011 [34] & 66 & $\begin{array}{c}\text { Robotic } \\
\text { da Vinci } \mathrm{Si}^{\mathrm{TM}}\end{array}$ & $\begin{array}{c}\text { Transperitoneal } \\
\text { Extravesical robotic bladder cuff } \\
\qquad(n=30) \\
\text { Open bladder cuff }(n=27) \\
\text { Transvesical bladder cuff }(n=5) \\
\text { Without bladder cuff }(n=4)\end{array}$ & $\begin{array}{c}195 \\
\text { (range 180-270) }\end{array}$ & $\begin{array}{l}\text { Overall rate } 30.76 \% \\
\text { Clavien I }(n=16) \\
\text { Clavien II }(n=9) \\
\text { Clavien IIIa }(n=2) \\
\text { Clavien IIIb }(n=2)\end{array}$ & $\begin{array}{l}\text { PSM } 6 \%-4 \text { patients } \\
\text { Bladder recurrence-16 } \\
\text { patients } \\
\text { New onset metastatic } \\
\text { disease-5 patients }\end{array}$ \\
\hline Hemal et al., 2011 [35] & 15 & $\begin{array}{c}\text { Robotic } \\
\text { da Vinci } \mathrm{Si}^{\mathrm{TM}}\end{array}$ & Transperitoneal & $\begin{array}{c}184 \\
\text { (range 147-250) }\end{array}$ & None & $\begin{array}{c}\text { PSM } 0 \% \\
\text { No recurrence }\end{array}$ \\
\hline
\end{tabular}


Table 3. Cont.

\begin{tabular}{|c|c|c|c|c|c|c|}
\hline Author, Year & $\begin{array}{l}\text { Number of } \\
\text { Patients }\end{array}$ & $\begin{array}{l}\text { Laparoscopic or } \\
\text { Robotic Technique }\end{array}$ & Approach & $\begin{array}{c}\text { Mean Operating Time } \\
(\text { min) }\end{array}$ & $\begin{array}{l}\text { Postoperative } \\
\text { Complications }\end{array}$ & Oncologic Outcomes \\
\hline Badani et al., 2014 [36] & 26 & Robotic & Transperitoneal & $\begin{array}{c}230 \\
\text { (range } 120-310 \text { ) }\end{array}$ & None & $\begin{array}{c}\text { PSM } 0 \% \\
\text { Bladder recurrence-4 } \\
\text { patients }\end{array}$ \\
\hline Zargar et al., 2014 [37] & 31 & Robotic & Transperitoneal & $300 \pm 69$ & $\begin{array}{c}\text { Overall rate } 19.35 \% \\
\text { Clavien I }(n=4) \\
\text { Clavien II }(n=1) \\
\text { Clavien III }(n=1)\end{array}$ & $\begin{array}{c}\text { PSM } 3,2 \% \\
\text { Bladder recurrence-7 } \\
\text { patients } \\
\text { New onset metastatic } \\
\text { disease- }-4 \text { patients }\end{array}$ \\
\hline Argun et al., 2016 [38] & 2 & $\begin{array}{c}\text { Robotic } \\
\text { da Vinci } \mathrm{Xi}_{\mathrm{i}}^{\mathrm{TM}}\end{array}$ & Transperitoneal & $\begin{array}{l}140 \\
150\end{array}$ & None & PSM $0 \%$ \\
\hline
\end{tabular}


Primary T1 high-grade bladder tumors treated conservatively with transurethral resection and BCG protocols have a $64.9 \%$ rate of recurrence and $33 \%$ rate of progression during the first 36 months of follow-up [39]. Factors that can potentially influence these outcomes are obesity, tumor size greater than $3 \mathrm{~cm}$, concomitant carcinoma in situ and increased preoperative neutrophil-to-lymphocytes ratio [40]. LRC with ICUD is a complex procedure [41]. Due to the limitations of laparoscopy in regard to reconstructive interventions, there is little experience in the field of ICUD, with few cases published in the literature [42-51] (Table 4).

The ileal conduit is the most frequently performed diversion, while the ileal neobladder is mainly reserved for selected younger patients, with fewer comorbidities, who can withstand longer anesthesia and are able to follow post-operative recovery protocols. Even though minimally invasive surgery is challenging, it lowers the risk of significant postoperative complications, both local (wound seroma and dehiscence, abdominal eventration) and general (anemia, pain, ileus) [41].

In the present study, 7 out of 21 cases underwent LRC with intracorporeal neobladder. The challenge for this procedure is to perform the reconstruction of the neobladder by manual suture, taking into consideration surgeon tiredness after the excisional part of the surgery. Shao et al. [52] conducted a study on 55 patients, using a similar technique and number of trocars. For the initial cases, they performed manual suture of the ileal reservoir, eventually advancing to Stapler ${ }^{\mathrm{TM}}$ systems. Despite simplification of the procedure by exclusion of the manual suture, the use of a stapler led to neobladder lithiasis in 2/30 patients. No significant difference was noted between the manually and the automatically sutured neobladder patients with respect to continence or urinary retention.

Adamczyk et al. [53] analyzed 260 patients who underwent either laparoscopic or open radical cystectomy. The laparoscopic approach was superior in terms of median operating time and estimated blood loss. Postoperative complications had higher Clavien scores in the open group (laparoscopic versus open radical cystectomy: 2.24 versus 2.65, $p=0.0001$ ), with 8 patients requiring reintervention for eventration, bleeding, urine leakage, infection, and peritonitis. However, when comparing a laparoscopy to robotics, there is no statistically significant difference in regard to oncological outcomes or major complications rate [54]. Also, similar functional outcomes have been reported (Table 4).

The limitation of our study resides in the limited follow-up of the patients. Long-term oncological and functional outcomes are needed in order to validate any surgical approach. However, the aim of our preliminary study was to show the feasibility of a 3D laparoscopic approach for some of the most complex urological procedures. 
Table 4. Literature review of most recent series of laparoscopic and robotic radical cystectomy with complete intracorporeal urinary diversion.

\begin{tabular}{|c|c|c|c|c|c|c|c|}
\hline Author, Year & $\begin{array}{l}\text { Number of } \\
\text { Patients }\end{array}$ & $\begin{array}{c}\text { Laparoscopic or } \\
\text { Robotic Technique }\end{array}$ & $\begin{array}{l}\text { Type of Urinary } \\
\text { Diversion }\end{array}$ & $\begin{array}{c}\text { Mean Operating Time } \\
\text { (min) }\end{array}$ & Postoperative Complications & Oncologic Outcomes & Functional Outcomes \\
\hline Kanno et al., 2020 [42] & 72 & Laparoscopic & Ileal conduit & 676 (range 612-740) & $\begin{array}{c}\text { Overall } \\
\text { first 30 days rate: } 50 \% \\
\text { Clavien IIIa-V }(n=14) \\
\text { Overall 30-90 days rate: } 28 \% \\
\text { Clavien IIIa-V: }(n=12)\end{array}$ & $\begin{array}{c}\text { PSM 1\%-1 patient } \\
\text { Local recurrence } 8 \%-6 \\
\text { patients } \\
\text { Distant recurrence } 14 \%-10 \\
\text { patients } \\
\text { Abdominal recurrence } \\
6 \%-4 \text { patients } \\
\text { Upper tract recurrence } \\
1 \%-1 \text { patient }\end{array}$ & Not reported \\
\hline Kubota et al., 2020 [43] & 30 & Laparoscopic & Ileal conduit & 688 (range 641-740) & $\begin{array}{c}\text { Overall rate: } 13 \% \\
\text { Ileus }(n=1) \\
\text { Abdominal abcess }(n=4) \\
\text { Acute pyelonephritis }(n=2) \\
\text { Anastomotic leak }(n=1) \\
\end{array}$ & PSM $3 \%-1$ patient & Not reported \\
\hline Xu et al., 2021 [44] & 12 & Laparoscopic & Neobladder & $414.6 \pm 52.2$ & $\begin{array}{c}\text { Overall rate: } 41.66 \% \\
\text { Urinary tract infection }(n=1) \\
\text { Lymphorrhagia }(n=1) \\
\text { Ureteroenteric anastomotic } \\
\text { stricture }(n=2) \\
\text { Metabolic abnormalities }(n=1)\end{array}$ & $\begin{array}{c}\text { PSM 0\% } \\
\text { No recurrence }\end{array}$ & $\begin{array}{c}\text { Day-time continence at } 12 \\
\text { months: } 83.3 \% \\
\text { Night-time continence at } \\
12 \text { months: } 58.3 \%\end{array}$ \\
\hline $\begin{array}{l}\text { Andras et al., } 2021 \\
\text { [Current paper] }\end{array}$ & 21 & 3D Laparoscopic & $\begin{array}{c}\text { Ileal conduit }(n=14) \\
\text { Neobladder }(n=7)\end{array}$ & $\begin{array}{l}461.09 \text { (range } 350-550) ; \\
496.27 \text { (range } 490-710 \text { ) }\end{array}$ & $\begin{array}{c}\text { Overall rate: } 23.8 \% \\
\text { Clavien I }(n=2) \\
\text { Clavien II }(n=2) \\
\text { Clavien IIIb }(n=1)\end{array}$ & $\begin{array}{c}\text { PSM } 4.76 \%-1 \text { patient } \\
\text { Local recurrence: } 4.76 \%-1 \\
\text { patient } \\
\text { New onset metastatic } \\
\text { disease: } 4.76 \%-1 \text { patient }\end{array}$ & $\begin{array}{c}\text { Neobladder: } \\
\text { Day-time continence at } 6 \\
\text { months: } 85.71 \%-6 \\
\text { patients }\end{array}$ \\
\hline Gok et al., 2019 [45] & 98 & Robotic & Neobladder & 493.2 (range 258-750) & $\begin{array}{c}\text { First } 30 \text { days-rate } 51.02 \% \text { : } \\
\text { Clavien I-II }(n=30) \\
\text { Clavien IIIa-V }(n=20) \\
\text { 30-90 days-rate } 13.26 \%: \\
\text { Clavien I-II }(n=6) \\
\text { Clavien IIIa-V }(n=7)\end{array}$ & $\begin{array}{c}\text { PSM 2\%-2 patients } \\
\text { Distant metastatic disease } \\
14.2 \%-14 \text { patients }\end{array}$ & $\begin{array}{c}\text { Day-time continence: } \\
60.6 \%-37 \text { patients } \\
\text { Night-time continence: } \\
40.9 \%-25 \text { patients } \\
\text { Mean International Index } \\
\text { of Erectile Function score } \\
\text { in those with no previous } \\
\text { erectile dysfunction: } 20.6\end{array}$ \\
\hline Brassetti et al., 2019 [46] & 137 & Robotic & Neobladder & 300 (range 240-350) & $\begin{array}{l}\text { Clavien III-V }(n=15) \\
\text { Readmission in the following } \\
\text { year: } 18(13 \%) \text { patients }\end{array}$ & $\begin{array}{c}\text { PSM } 3 \%-4 \text { patients } \\
\text { Disease recurrence at } 12 \\
\text { months: } 7 \%\end{array}$ & $\begin{array}{c}\text { Day-time continence at } 12 \\
\text { months: } 79 \%\end{array}$ \\
\hline
\end{tabular}


Table 4. Cont.

\begin{tabular}{|c|c|c|c|c|c|c|c|}
\hline Author, Year & $\begin{array}{c}\text { Number of } \\
\text { Patients }\end{array}$ & $\begin{array}{c}\text { Laparoscopic or } \\
\text { Robotic Technique }\end{array}$ & $\begin{array}{l}\text { Type of Urinary } \\
\text { Diversion }\end{array}$ & $\begin{array}{c}\text { Mean Operating Time } \\
\text { (min) }\end{array}$ & Postoperative Complications & Oncologic Outcomes & Functional Outcomes \\
\hline Tan et al., 2019 [47] & 59 & Robotic & Ileal conduit & 330 (range 300-368) & $\begin{array}{c}\text { Overall } \\
\text { first 30 days rate: } 48.4 \% \\
\text { Clavien IIIa-V }(n=5) \\
\text { Overall 30-90 days rate: } 16.2 \% \\
\text { Clavien IIIa-V }(n=5)\end{array}$ & PSM $8.5 \%-5$ patients & Not reported \\
\hline Hosseini et al., 2020 [48] & 158 & $\begin{array}{c}\text { Robotic } \\
\text { da Vinci } \mathrm{Si}^{\mathrm{TM}}\end{array}$ & Neobladder & $359 \pm 98$ & $\begin{array}{c}\text { Overall rate } 23 \% \\
\text { First } 30 \text { days: } \\
\text { Clavien IIIa-V }(n=29) \\
30-90 \text { days: } \\
\text { Clavien IIIa-V }(n=8) \\
\end{array}$ & $\begin{array}{l}\text { PSM } 1 \%-2 \text { patients } \\
\text { Tumor recurrence in } 26 \\
\text { patients ( } 41 \text { sites) }\end{array}$ & Not reported \\
\hline Porreca et al., 2020 [49] & 83 & Robotic & $\begin{array}{l}\text { Ileal conduit }(n=32) \\
\text { Neobladder }(n=51)\end{array}$ & 410 (range 351-460) & $\begin{array}{c}\text { Overall first } 30 \text { days rate: } 35 \% \\
\text { Clavien I-II }(n=33) \\
\text { Clavien IIIa-V }(n=9) \\
\text { Overall } 30-90 \text { days rate: } 20 \% \\
\text { Clavien I-II }(n=9) \\
\text { Clavien IIIa-V }(n=10)\end{array}$ & PSM $-3 \%-3$ patients & $\begin{array}{c}\text { Day-time continence at } 12 \\
\text { months: } 90.2 \%-46 \\
\text { patients } \\
\text { Night-time continence at } \\
12 \text { months: } 70.6 \%-36 \\
\text { patients } \\
\text { Potency rate at } 12 \text { months: } \\
31 \%-31 \text { patients }\end{array}$ \\
\hline $\begin{array}{c}\text { Dell'Oglio et al., } 2021 \\
\text { [51] }\end{array}$ & 164 & Robotic & $\begin{array}{c}\text { Ileal conduit }(n=146) \\
\text { Neobladder }(n=18)\end{array}$ & 350 (range 327-360) & $\begin{array}{c}\text { Overall rate: } 35 \% \\
\text { Clavien II-V }(n=57)\end{array}$ & $\begin{array}{l}\text { PSM 7\%-11 patients } \\
\text { Recurrence at } 18 \text { months: } \\
33(20 \%) \text { patients }\end{array}$ & $\begin{array}{c}\text { Neobladder: } \\
\text { Day-time continence: } \\
78 \%-14 \text { patients } \\
\text { Night-time continence: } \\
50 \%-9 \text { patients }\end{array}$ \\
\hline
\end{tabular}




\section{Conclusions}

In the era of robotic surgery, a laparoscopy remains a plausible alternative for most complex oncological cases. With increased experience, difficult interventions can be performed in a safe, cost-effective, and minimally invasive way.

Author Contributions: I.A., A.T., T.T. and N.C. have given substantial contributions to the conception and the design of the manuscript; P.M., I.P., A.B., D.V.S., M.B. to acquisition, analysis and interpretation of the data. All authors have participated to drafting the manuscript, I.C. and N.C. revised it critically. All authors have read and agreed to the published version of the manuscript.

Funding: This research received no external funding.

Institutional Review Board Statement: The study was conducted according to the guidelines of the Declaration of Helsinki, and approved by the Ethics Committee of Municipal Clinical Hospital Cluj-Napoca (protocol code 28/2020, approved on 6 October 2020).

Informed Consent Statement: Informed consent was obtained from all subjects involved in the study.

Data Availability Statement: All the data supporting the result are available upon request from the corresponding author.

Conflicts of Interest: The authors declare no conflict of interest.

\section{References}

1. Vartolomei, M.D.; Matei, D.V.; Renne, G.; Tringali, V.M.; Crisan, N.; Musi, G.; Mistretta, F.A.; Russo, A.; Cozzi, G.; Cordima, G.; et al. Robot-assisted Partial Nephrectomy: 5-yr Oncological Outcomes at a Single European Tertiary Cancer Center. Eur. Urol. Focus 2019, 5, 636-641. [CrossRef]

2. Harryman, O.A.; Davenport, K.; Keoghane, S.; Keeley, F.X.; Timoney, A.G. A Comparative Study of Quality of Life Issues Relating to Open Versus Laparoscopic Nephrectomy: A Prospective Pragmatic Study. J. Urol. 2009, 181, 998-1003. [CrossRef]

3. Mullen, E.; Ahmed, K.; Challacombe, B. Systematic review of open versus laparoscopic versus robot-assisted nephroureterectomy. Rev. Urol. 2017, 19, 32-43.

4. Athanasiadis, G.; Bourdoumis, A.; Masood, J. Is it the End for Urologic Pelvic Laparoscopic Surgery? Surg. Laparosc. Endosc. Percutaneous Tech. 2017, 27, 139-146. [CrossRef]

5. Childers, C.P.; Maggard-Gibbons, M. Estimation of the Acquisition and Operating Costs for Robotic Surgery. JAMA 2018, 320, 835-836. [CrossRef]

6. Sheetz, K.H.; Claflin, J.; Dimick, J.B. Trends in the Adoption of Robotic Surgery for Common Surgical Procedures. JAMA Netw. Open 2020, 3, e1918911. [CrossRef] [PubMed]

7. Andras, I.; Crisan, N.; Gavrilita, M.; Coman, R.-T.; Nyberg, V.; Coman, I. Every setback is a setup for a comeback: 3D laparoscopic radical prostatectomy after robotic radical prostatectomy. J. BUON 2017, 22, 87-93. [PubMed]

8. Nguyen, D.H.; Nguyen, B.H.; Van Nong, H.; Tran, T.H. Three-dimensional laparoscopy in urology: Initial experience after 100 cases. Asian J. Surg. 2019, 42, 303-306. [CrossRef]

9. Spiers, A.J.; Baillie, S.; Pipe, T.G.; Asimakopolous, G. Negating the fulcrum effect in manual laparoscopic surgery: Investigating skill acquisition with a haptic simulator. Int. J. Med Robot. Comput. Assist. Surg. 2017, 13, e1837. [CrossRef] [PubMed]

10. Cicione, A.; Autorino, R.; Breda, A.; De Sio, M.; Damiano, R.; Fusco, F.; Greco, F.; Carvalho-Dias, E.; Mota, P.; Nogueira, C.; et al. Three-dimensional vs. Standard Laparoscopy: Comparative Assessment Using a Validated Program for Laparoscopic Urologic Skills. Urology 2013, 82, 1444-1450. [CrossRef]

11. Abaza, R. The robotic surgery era and the role of laparoscopy training. Ther. Adv. Urol. 2009, 1, 161-165. [CrossRef]

12. Crisan, N.; Neiculescu, C.; Matei, D.V.; Coman, I. Robotic retroperitoneal approach-A new technique for the upper urinary tract and adrenal gland. Int. J. Med Robot. Comput. Assist. Surg. 2013, 9, 492-496. [CrossRef]

13. Crisan, N.; Andras, I.; Grad, D.-L.; Telecan, T.; Coman, R.-T.; De Cobelli, O.; Matei, D.V.; Coman, I. Dual Combined Laparoscopic Approach for Renal-Cell Carcinoma with Renal Vein and Level I-II Inferior Vena Cava Thrombus: Our Technique and Initial Results. J. Endourol. 2018, 32, 837-842. [CrossRef]

14. Sanli, O.; Tefik, T.; Erdem, S.; Oktar, T.; Tunc, M.; Ozcan, F. Use of a combined retroperitoneoscopic and transperitoneal laparoscopic technique for the management of renal cell carcinoma with level I tumor thrombi. J. Minimal Access Surg. 2013, 9, 168-172. [CrossRef] [PubMed]

15. Tang, Q.; Wang, T.; Li, X.; Zhang, Z.; Song, G.; He, Z.; Zhou, L. Renal Cell Carcinoma with Infrahepatic Vena Caval Tumor Thrombus Treated with a Novel Combined Retroperitoneal and Transperitoneal Pure Laparoscopic Procedure. Urology 2014, 83, e9-e10. [CrossRef]

16. Chopra, S.; Simone, G.; Metcalfe, C.; Abreu, A.L.D.C.; Nabhani, J.; Ferriero, M.; Bove, A.M.; Sotelo, R.; Aron, M.; Desai, M.M.; et al. Robot-assisted Level II-III Inferior Vena Cava Tumor Thrombectomy: Step-by-Step Technique and 1-Year Outcomes. Eur. Urol. 2017, 72, 267-274. [CrossRef] 
17. Gill, I.S.; Cacciamani, G.E.; Duddalwar, V.; Thangathurai, D.; Cunningham, M. Renal cancer with extensive level IV intracardiac tumour thrombus removed by robot. Lancet 2020, 396, e88. [CrossRef]

18. Wang, W.; Wang, L.; Xu, J.; Adams, T.S.; Tian, Y.; Lv, W. Pure Retroperitoneal Laparoscopic Radical Nephrectomy for Right Renal Masses with Renal Vein and Inferior Vena Cava Thrombus. J. Endourol. 2014, 28, 819-824. [CrossRef] [PubMed]

19. Shao, P.; Li, J.; Qin, C.; Lv, Q.; Ju, X.; Li, P.; Shao, Y.; Ni, B.; Yin, C. Laparoscopic Radical Nephrectomy and Inferior Vena Cava Thrombectomy in the Treatment of Renal Cell Carcinoma. Eur. Urol. 2015, 68, 115-122. [CrossRef] [PubMed]

20. Tohi, Y.; Makita, N.; Suzuki, I.; Suzuki, R.; Kubota, M.; Sugino, Y.; Inoue, K.; Kawakita, M. En bloc laparoscopic radical nephrectomy with inferior vena cava thrombectomy: A single-institution experience. Int. J. Urol. 2018, 26, 363-368. [CrossRef]

21. Cinar, O.; Gunseren, K.O.; Cicek, C.; Vuruskan, B.A.; Vuruskan, H. Laparoscopic Transperitoneal Radical Nephrectomy for Renal Masses with Level I and II Thrombus. J. Laparoendosc. Adv. Surg. Tech. 2019, 29, 35-39. [CrossRef] [PubMed]

22. Tian, X.; Hong, P.; Liu, Z.; Huang, Y.; Wang, G.; Hou, X.; Zhang, S.; Ma, L. En bloc retroperitoneal laparoscopic radical nephrectomy with inferior vena cava thrombectomy for renal cell carcinoma with level 0 to II venous tumor thrombus: A single-center experience. Cancer 2020, 126, 2073-2078. [CrossRef] [PubMed]

23. Abaza, R. Initial Series of Robotic Radical Nephrectomy with Vena Caval Tumor Thrombectomy. Eur. Urol. 2011, 59, 652-656. [CrossRef] [PubMed]

24. Wu, S.; Peng, C.; Li, H.Z.; Huang, Q.; Fan, Y.; Gao, Y.; Zhang, X.; Wang, B.; Ma, X. Robotic retroperitoneal versus transperitoneal inferior vena cava thrombectomy: Right-sided cases with level I-II tumor thrombus. J. Endourol. 2021. [CrossRef]

25. Zlotta, A.R. Should urologists always perform a bladder cuff resection during nephroureterectomy, and which method should they use? Eur. Urol. 2010, 57, 970-972. [CrossRef] [PubMed]

26. Ghazi, A.; Shefler, A.; Gruell, M.; Zimmermann, R.; Janetschek, G. A Novel Approach for a Complete Laparoscopic Nephroureterectomy with Bladder Cuff Excision. J. Endourol. 2010, 24, 415-419. [CrossRef] [PubMed]

27. Liu, P.; Fang, N.; Xiong, G.; Yang, K.; Zhang, L.; Yao, L.; Zhang, C.; Li, X.; He, Z.; Zhou, L. A Novel and Simple Modification for Management of Distal Ureter During Laparoscopic Nephroureterectomy Without Patient Repositioning: A Bulldog Clamp Technique and Description of Modified Port Placement. J. Endourol. 2016, 30, 195-200. [CrossRef]

28. Wu, G.; Wang, T.; Wang, J.; Yuan, H.; Cui, Y.; Wu, J. Complete retroperitoneal laparoscopic nephroureterectomy with bladder cuff excision for upper tract urothelial carcinoma without patient repositioning: A single-center experience. J. Int. Med. Res. 2020, 48. [CrossRef]

29. Hattori, R.; Yoshino, Y.; Komatsu, T.; Matsukawa, Y.; Ono, Y.; Gotoh, M. Pure laparoscopic complete excision of distal ureter with a bladder cuff for upper tract urothelial carcinoma. World J. Urol. 2008, 27, 253-258. [CrossRef]

30. Veccia, A.; Antonelli, A.; Francavilla, S.; Simeone, C.; Guruli, G.; Zargar, H.; Perdoná, S.; Ferro, M.; Carrieri, G.; Hampton, L.J.; et al. Robotic versus other nephroureterectomy techniques: A systematic review and meta-analysis of over 87,000 cases. World J. Urol. 2019, 38, 845-852. [CrossRef]

31. Gillan, A.; Alexander, E.; Townell, N.; Nabi, G. Laparoscopic En Bloc Resection of Ureter with a Cuff of Bladder During Radical Nephroureterectomy for Lower Ureteric Tumors: A Matched-Paired Analysis. J. Laparoendosc. Adv. Surg. Tech. 2013, 23, 626-631. [CrossRef]

32. Miyake, M.; Nishimura, N.; Aoki, K.; Ohmori, C.; Shimizu, T.; Owari, T.; Hori, S.; Morizawa, Y.; Gotoh, D.; Nakai, Y.; et al. Initial experience of complete laparoscopic radical nephroureterectomy combined with transvesical laparoscopic excision of distal ureter in patients with upper urinary tract cancer. World J. Surg. Oncol. 2020, 18, 1-11. [CrossRef]

33. Ye, K.; Zhong, Z.; Zhu, L.; Ren, J.; Xiao, M.; Liu, W.; Xiong, W. Modified transperitoneal versus retroperitoneal laparoscopic radical nephroureterectomy in the management of upper urinary tract urothelial carcinoma: Best practice in a single center with updated results. J. Int. Med Res. 2020, 48. [CrossRef] [PubMed]

34. Campi, R.; Cotte, J.; Sessa, F.; Seisen, T.; Tellini, R.; Amparore, D.; Mormile, N.; Gobert, A.; Mari, A.; Porpiglia, F.; et al. Robotic radical nephroureterectomy and segmental ureterectomy for upper tract urothelial carcinoma: A multi-institutional experience. World J. Urol. 2019, 37, 2303-2311. [CrossRef] [PubMed]

35. Hemal, A.K.; Stansel, I.; Babbar, P.; Patel, M. Robotic-assisted Nephroureterectomy and Bladder Cuff Excision Without Intraoperative Repositioning. Urology 2011, 78, 357-364. [CrossRef] [PubMed]

36. Badani, K.K.; Rothberg, M.B.; Bergman, A.; Silva, M.V.; Shapiro, E.Y.; Nieder, A.; Patel, T.; Bhandari, A. Robot-Assisted Nephroureterectomy and Bladder Cuff Excision Without Patient or Robot Repositioning: Description of Modified Port Placement and Technique. J. Laparoendosc. Adv. Surg. Tech. 2014, 24, 647-650. [CrossRef] [PubMed]

37. Zargar, H.; Krishnan, J.; Autorino, R.; Akca, O.; Brandao, L.F.; Laydner, H.; Samarasekera, D.; Ko, O.; Haber, G.-P.; Kaouk, J.H.; et al. Robotic Nephroureterectomy: A Simplified Approach Requiring No Patient Repositioning or Robot Redocking. Eur. Urol. 2014, 66, 769-777. [CrossRef]

38. Argun, O.B.; Mourmouris, P.; Tüfek, I.; Tuna, M.B.; Keskin, S.; Öbek, C.; Kural, A.R. Radical Nephroureterectomy Without Patient or Port Repositioning Using the Da Vinci Xi Robotic System: Initial Experience. Urology 2016, 92, 136-139. [CrossRef]

39. Ferro, M.; Di Lorenzo, G.; Vartolomei, M.D.; Bruzzese, D.; Cantiello, F.; Lucarelli, G.; Musi, G.; Di Stasi, S.; Hurle, R.; Guazzoni, G.; et al. Absolute basophil count is associated with time to recurrence in patients with high-grade T1 bladder cancer receiving bacillus Calmette-Guérin after transurethral resection of the bladder tumor. World J. Urol. 2019, 38, 143-150. [CrossRef] 
40. Ferro, M.; Di Lorenzo, G.; Buonerba, C.; Lucarelli, G.; Russo, G.I.; Cantiello, F.; Abu Farhan, A.R.; Di Stasi, S.; Musi, G.; Hurle, R.; et al. Predictors of Residual T1 High Grade on Re-Transurethral Resection in a Large Multi-Institutional Cohort of Patients with Primary T1 High-Grade/Grade 3 Bladder Cancer. J. Cancer 2018, 9, 4250-4254. [CrossRef]

41. Boc, A.; Crisan, N.; Vesa, S.C.; Coman, I.; Stanca, V.D.; Andras, I. The impact of minimal invasive surgery on early complications and mortality after radical cystectomy for muscle-invasive urothelial bladder cancer. J. BUON 2018, 23, 104-110.

42. Kanno, T.; Inoue, T.; Kawakita, M.; Ito, K.; Okumura, K.; Yamada, H.; Kubota, M.; Fujii, M.; Shimizu, Y.; Yatsuda, J.; et al. Perioperative and oncological outcomes of laparoscopic radical cystectomy with intracorporeal versus extracorporeal ileal conduit: A matched-pair comparison in a multicenter cohort in Japan. Int. J. Urol. 2020, 27, 559-565. [CrossRef]

43. Kubota, M.; Kokubun, H.; Yamaguchi, R.; Murata, S.; Makita, N.; Suzuki, I.; Suzuki, R.; Abe, Y.; Tohi, Y.; Tsutsumi, N.; et al. Surgical outcomes and learning curve of totally intracorporeal ileal conduit urinary diversion following laparoscopic radical cystectomy at a single institution. Asian J. Endosc. Surg. 2020. [CrossRef]

44. Xu, P.; Chen, B.; Xu, A.; Yuan, D.; Zhang, Y.; Liu, C. Initial Experience with Intracorporeal Laparoscopic Radical Cystectomy and Detaenial Sigmoid Neobladder Reconstruction. Eur. Urol. 2021, 79, 545-551. [CrossRef] [PubMed]

45. Gok, B.; Atmaca, A.F.; Canda, A.E.; Asil, E.; Koc, E.; Ardicoglu, A.; Balbay, M.D. Robotic Radical Cystectomy with Intracorporeal Studer Pouch Formation for Bladder Cancer: Experience in Ninety-Eight Cases. J. Endourol. 2019, 33, 375-382. [CrossRef] [PubMed]

46. Brassetti, A.; Tuderti, G.; Anceschi, U.; Ferriero, M.; Guaglianone, S.; Gallucci, M.; Simone, G. Combined reporting of surgical quality, cancer control and functional outcomes of robot-assisted radical cystectomy with intracorporeal orthotopic neobladder into a novel trifecta. Minerva Urol. Nefrol. 2019, 71, 590-596. [CrossRef] [PubMed]

47. Tan, T.W.; Nair, R.; Saad, S.; Thurairaja, R.; Khan, M.S. Safe transition from extracorporeal to intracorporeal urinary diversion following robot-assisted cystectomy: A recipe for reducing operative time, blood loss and complication rates. World J. Urol. 2019, 37, 367-372. [CrossRef] [PubMed]

48. Hosseini, A.; Mortezavi, A.; Sjöberg, S.; Laurin, O.; Adding, C.; Collins, J.; Wiklund, P.N. Robot-assisted intracorporeal orthotopic bladder substitution after radical cystectomy: Perioperative morbidity and oncological outcomes-A single-institution experience. BJU Int. 2020, 126, 464-471. [CrossRef] [PubMed]

49. Porreca, A.; Bianchi, F.M.; Romagnoli, D.; D’Agostino, D.; Corsi, P.; Giampaoli, M.; Salvaggio, A.; Bianchi, L.; Schiavina, R.; Brunocilla, E.; et al. Robot-assisted radical cystectomy with totally intracorporeal urinary diversion: Surgical and early functional outcomes through the learning curve in a single high-volume center. J. Robot. Surg. 2019, 14, 261-269. [CrossRef]

50. Cacciamani, G.E.; Winter, M.; Medina, L.G.; Ashrafi, A.N.; Miranda, G.; Tafuri, A.; Landsberger, H.; Lin-Brande, M.; Rajarubendra, N.; Abreu, A.D.C.; et al. Radical cystectomy pentafecta: A proposal for standardisation of outcomes reporting following robot-assisted radical cystectomy. BJU Int. 2020, 125, 64-72. [CrossRef]

51. Dell'Oglio, P.; Mazzone, E.; Lambert, E.; Vollemaere, J.; Goossens, M.; Larcher, A.; Van Der Jeugt, J.; Devos, G.; Poelaert, F.; Uvin, P.; et al. The Effect of Surgical Experience on Perioperative and Oncological Outcomes After Robot-assisted Radical Cystectomy with Intracorporeal Urinary Diversion: Evidence from a Referral Centre with Extensive Experience in Robotic Surgery. Eur. Urol. Focus 2021, 7, 352-358. [CrossRef] [PubMed]

52. Shao, P.; Li, P.; Ju, X.; Qin, C.; Li, J.; Lv, Q.; Meng, X.; Yin, C. Laparoscopic Radical Cystectomy With Intracorporeal Orthotopic Ileal Neobladder: Technique and Clinical Outcomes. Urology 2015, 85, 368-374. [CrossRef] [PubMed]

53. Adamczyk, P.; Juszczak, K.; Kadłubowski, M.; Ostrowski, A.; Maciukiewicz, P.; Drewa, T. Can laparoscopic cystectomy become the method of choice in the treatment of invasive urothelial urinary bladder cancer? Adv. Clin. Exp. Med. 2020, 29, 301-304. [CrossRef]

54. Su, S.; Gu, L.; Ma, X.; Li, H.; Wang, B.; Shi, T.; Zhang, X. Comparison of Laparoscopic and Robot-assisted Radical Cystectomy for Bladder Cancer: Perioperative and Oncologic Outcomes. Clin. Genitourin. Cancer 2019, 17, e1048-e1053. [CrossRef] [PubMed] 